\title{
The Role of Women in Promoting Agricultural Productivity And Developing Skills For Improved Quality of Life In Rural Areas.
}

\author{
Adenugba, A.O \& Raji-Mustapha, N. O. \\ Agricultural and Rural Productivity Department, National Productivity Centre, Abuja
}

\begin{abstract}
The paper presents different aspects of issues surrounding Women affairs in rural Communities in Nigeria. We investigated the role being played by rural women in an agricultural setting. Women were found to be providers of large proportion of labour in rural agricultural communities, from subsistence to commercial farming. We also found that one of the main causes of this phenomenon is the rural-urban migration of men in search of paid employment in towns and cities, either in their own country or abroad. As men leave their rural homes, the role of women in agricultural production becomes increasingly dominant. Our investigation revealed that Rural women produce as much as $80 \%$ of the food we eat. The Nigerian rural women are the chief source of agricultural labour, yet are also the central victims of hunger, malnutrition, poverty, high fertility and maternal mortality rates. The result is progressive reduction in productivity and output. There is therefore urgent need to increase women empowerment in Nigeria, for higher productivity.
\end{abstract}

Key words: - Productivity, Rural women, Skills development, Empowerment.

\section{INTRODUCTION}

Agriculture plays an important role in most non-industrial economies, as a major contributor to the country's export earnings and as a source of employment and livelihood. Official statistics often underestimate the value of women's work and their overall contribution to national wealth. Women continue to provide a large proportion of the labour that goes into agriculture.- Food and Agricultural Organization's (FAO's) estimates show that women represent a substantial share of the total agricultural labour force, as individual food producers or as agricultural workers. It further stated that around two-thirds of the female labour force in developing economies is engaged in agricultural work.

FAO has noted that while the overall proportion of the economically active population (EAP) working in agriculture declined during the 1990s, the percentage of economically active women working in agriculture at the global level remained nearly 50 percent through 2000, with an even higher percentage in developing countries (61 percent) and in Least Developed Countries (LDCs )(79 percent). Furthermore, although FAO projections to 2010 indicate a continued reduction in the overall female participation in agriculture globally, the percentage of economically active women working in agriculture in LDCs is projected to remain above 70 percent.

The chart below compares FAO estimates of the proportions of the female economically active population working in agriculture, first at the global level, and then for developing countries, low-income food deficit countries (LIFDCs) and the Least Developed Countries (LDCs)

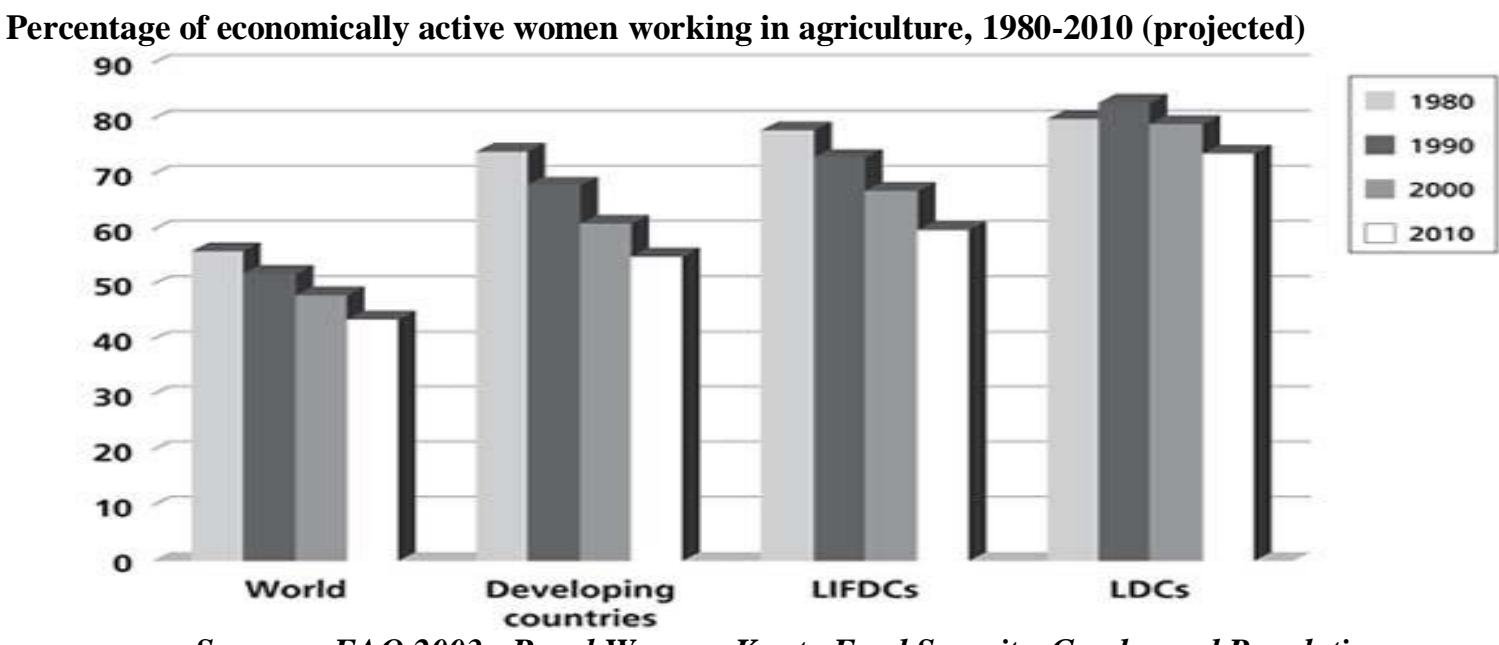

Source: FAO 2003 - Rural Women: Key to Food Security, Gender and Population 
In many parts of the world today, including Nigeria. there is an increasing trend towards what has been called the feminization of agriculture. One of the main causes of this phenomenon is the rural-urban migration of men in search of paid employment in towns and cities, either in their own country or abroad. As men leave their rural homes, the role of women in agricultural production becomes increasingly dominant.

All too often the feminization of agriculture brings with it a feminization of poverty. This is not only due to the increased proportion of females in the rural areas of the developing world, where the poor and hungry are concentrated but is also related to purchasing power and the way money is used. In many rural areas of Nigeria, gender-biased land tenure systems limit women's access to good farming land.

Furthermore, women in Nigeria have little or no access to credit, and hence to the capital they need to be able to expand their production capacity. Not surprisingly, their households are often the hardest hit by malnutrition and food insecurity. The opportunities for rural women to diversify their incomes are also limited. Many cultures proscribe their working outside the home and, even where this is not the case, rural women are so overburdened with the chores of mere subsistence that the possibilities of their being involved in non-farm income-generating activities are severely curtailed.

Women farmers particularly in rural areas of Nigeria have always worked, and their labour plays a key role in the survival of millions of families'. Most rural women are the invisible farmers in Nigeria and form the backbone of rural development. The underlying fact is that more than half of Nigeria's food is produced by women. In rural areas of Nigeria, where food production is the principal economic activity, women provide up to 80 percent of the food consumed in their own homes as shown in Table 1. Yet their families - the rural poorform the majority of the world's 800 million chronically hungry people.

About $70 \%$ of the agricultural workers, $80 \%$ of food producers, and $10 \%$ of those who process basic foodstuffs are women and they also undertake 60 to $90 \%$ of the rural marketing; thus making up more than twothirds of the workforce in agricultural production (FAO, 1985) as shown in Table 1.

\begin{tabular}{|l|l|l|}
\hline S/N & ACTIVITY & $\%$ INVOLVEMENT \\
\hline 1. & African workers & 70 \\
\hline 2. & Food producers & 80 \\
\hline 3. & Basic foodstuff processing & 10 \\
\hline 4. & Rural Marketing & $60-90$ \\
\hline 5. & $\%$ in workforce in West Africa & 80 \\
\hline
\end{tabular}

Table 1: Percentage of women involvement in agriculture (FAO, 1995)

Women and rural women in particular, have traditionally achieved more with less. In an average day they plant crops and plough or harvest fields; they fish, gather firewood and fruits and cultivate home gardens; they fetch water, cook and process food, wash clothes and care for children and the elderly. Despite this, women have no limited rights to own the land that they $\mathrm{f}$ arm.

The Nigerian women farmers are involved in several agricultural practices, processing and marketing of products. Women contribute immensely to the agricultural production sector of the Nigerian economy. However, because of their mode of production which is basically at the domestic and subsistence levels, women's contributions are usually underestimated not given its rightful recognition and indeed devalued. To put it more succinctly, they are not measured in economic terms. Viewed from this perspective, the rural women-folk are seen as dependent and marginal to agricultural production and indeed to rural development.

\section{WOMEN IN THE AGRICULTURAL DEVELOPMENT PROCESS}

\subsection{The Triple Role of Rural Women}

In most Third World households women have a triple role. The contributions of rural women to the economy can be examined from three (3) broad perspectives, namely:

(i) Reproductive work (child bearing/rearing)

(ii) Productive work(Family and household maintenance)

(iii) Community managing and Community Politics

\section{(i) Reproductive Work}

The reproductive role comprises child bearing and rearing responsibilities and domestic tasks undertaken by women, required to guarantee the maintenance and reproduction of the labour force. It includes not only biological reproduction but also the care and maintenance of the workforce (husband and working children) and the future workforce (infants and school going children). 74\% of Nigerian women's reproductive life is spent in marriage.

(ii) Productive Work 
Productive work in this context is broadly defined as a task or activity which generates an income and, therefore, has an exchange value either actual or potential. The productive role comprises work done by both women and men for payment in cash or kind. It includes both market production with an exchange value, and subsistence home production with an actual use-value, but also potential exchange value.

Studies have shown that the time taken for the care of children and household responsibilities absorb more of a rural woman's time than her income-earning activities on a daily basis. Most typical rural families in

Nigeria depend on firewood for cooking and this responsibility is borne mostly by women. The amount of daily labour time spent collecting firewood is estimated to average about 2 hours per family. Mostly rural women spend considerable time each day preparing food for the family consumption. Since most households obtain their foodstuffs in virtually unprocessed state, a lot of time and energy are spent in these tasks.

\section{(iii) Community Managing and Community Politics}

The community managing role comprises activities undertaken primarily by rural women at the community level as an extension of their reproductive role. This is to ensure the provision and maintenance of scarce resources of collective consumption, such as water, healthcare and education. Community managing then is defined as the work undertaken at the community level, around the allocation, provisioning and managing of items of collective consumption.

\section{THE ROLE OF WOMEN IN RURAL DEVELOPMENT}

Rural women in Nigeria, working twelve (12) or more hours a day, maintaining their homes, caring for their children, growing and preparing the food that nourishes our nation and earning the incomes that are critical to family welfare, are everyday making fundamental contributions to both economic growth and national development. Rural women produce as much as $80 \%$ of the food we eat. The Nigerian rural women are the chief source of agricultural labour yet the central victim of hunger, malnutrition, poverty, high fertility and maternal mortality rates. The result is progressive reduction in productivity and output.

Majority of the rural women are not in agricultural food production by choice, they grew up into it as the only and natural role. Therefore, their work as mothers, wives and citizens have always been combined with essential economic roles as food producers, income earners and managers of personal and household budgets. They play their reproductive and nurturing roles and in addition engage in a wide range of agricultural and off farm and household activities. Rural women's domestic chores include fetching water and firewood over long distances, washing, sweeping and pounding - all tedious and exhausting in an environment of dwindling food resources and increasing health hazards. Rural women are effective agents of community mobilization and social development. Rural women play a pivotal role in producing staple crops, livestock, fisheries, forestry and in food-processing storage and marketing.

\section{CONSTRAINTS FACED BY RURAL WOMEN}

Rural women face different constraints on their agricultural and economic activities than do men. Four(4) distinct underlying mechanisms account for this:

(i) The burden of reproduction;

(ii) Asymmetric rights and obligations within the household;

(iii) Different role models;

(iv) Women farmers' limited access to resources and information.

These four factors largely account for the different allocation of labour between women and men. They also explain why the time of women tends to be confined to activities that produce lower returns and that cannot be easily shifted in response to changes in incentives. As a result, rural women are usually concentrated in food production and small scale marketing and are substantially under-represented in the formal export agriculture.

\section{(i) The Burden of Reproduction}

The physical demands of child-bearing and breast feeding strain health, and recent studies clearly show that the health of women farmers is crucial to their productivity. This deterioration can be reversed, however, of rural women become involved in income earning opportunities. Child-rearing responsibilities limit the ability to continue formal employment, hence women become confined to economic activities in which the uncertainty of being able to work is relatively unimportant.

In addition, in the absence of birth control it is difficult for a household to plan for long-term investments, and therefore some of them may be postponed. There is evidence that certain investments may be discouraged if the mother is young, because of the possibility of an increase in family size. Thus, the adoption 
of birth control would have a rapid and powerful effect on the capacity of households to undertake longer term investments in education, and hence, to raise the income of these rural women in the long run.

\section{(ii) Asymmetric Rights and Obligations within the household}

Women farmers are expected to produce subsistence food crops, to weed all crops, to gather firewood, to fetch water and to cook and rear children. In return, men provide cash for the household and usually are responsible for the allocation of land. This pattern of reciprocal obligations often is unequal in the sense that the obligations of rural women are more time consuming than that of men. As a result, women farmers have to work considerably more hours than men. Part of this work is on crops which men control the profits. Thus, women farmers must work without knowing for certain whether they will get something out of it for themselves or their children.

One of the consequences of this arrangement is that women farmers have less time for activities, including those that could provide income.

\section{(iii) Limited access to resources and information}

Women farmers often encounter discrimination outside the household, which limits their access to resources and information. Unlike the other constraints faced by women, which may be deeply embedded in social custom, discrimination outside the household is something that policies and programmes can help change. In order to grow and or process food, women farmers need a number of inputs, most basically land and labour, for those seeking to increase their productivity and incomes. Other inputs are required, especially credit, improved technology, and training or extension services. Women should have unequal access to, and control over all these resource.

\section{(a) Access to Land}

Land provide not jus basis of production for the farm, smallholding or vegetable strip but the source of water, firewood, foods and materials used in non-food production, such as clay for pots and dyes for cloth. Land titles also give access to other resources, most importantly credit, for which they serve as collateral.

\section{(b) Access to Credit}

The availability of credit is essential for improving productivity and enhancing income, and also at times, for making seasonal shortfalls. Short term credit may be for seeds and fertilizers, longer term credit for tools and perhaps to set up small-scale enterprise such as a poultry farm. Women farmers have limited access to credit. Even where credit is available, access requires collateral - either assets or reputation (land title or livestock) to guarantee loans, and in part of their exclusion from male-oriented information networks and extension services. The potential productivity of rural women and ability to repay loans are also frequently underestimated or even ridiculed, although their participation in the schemes to which they have been admitted shows a good record of repayment and yield as good or as better than men.

\section{(c) Access to Extension Services and Training}

Agricultural extension programmes ensure that information on new technologies and plant varieties reaches the farmers. However, it is common practice to direct extension and training services primarily to men. A recent FAO survey showed that female farmers receive only 5 percent of all agricultural extension services world-wide and that only 15 percent of the world's extension agents are women.

Agricultural extension services in many African countries still design their programmes as if all farmers were men. This is because of the erroneous belief that men are the main decision-makers in agriculture. It also reflects the fact that the extension service is overwhelmingly staffed by men. As a result male agricultural extension agents tend to provide production information to male farmers while female home economic extension agents, who target women, concentrate more on subjects such as food processing and crafts. Extension programmes rarely identify women as an integral part of the target audience. For long, policies have been based on the assumption- proved wrong by studies - that information conveyed to the male head of a household will be passed on to its female members. Furthermore, policy makers fail to recognize that men and women are often responsible for different crops, livestock, tasks and income - generating activities and that their extension needs differ.

\section{(d) Availability of Appropriate Agricultural Technology.}

Increasing productivity - whether of food or cash crops - may require certain technological inputs. It is now recognized, however, that the introduction of modern technology in situations of inequality in land and resources ownership runs the risk of making inequality worse. 
An ILO workshop on women and land in Africa noted the divergent interests and widening productivity gaps between men and women. More men have the opportunity to acquire new skills and to raise productivity through mechanization.

Women farmers with less income, limited access to credit, and secondary role in cash cropping, are particularly unlikely to be the beneficiaries of high-tech government assistance or foreign aid packages. Women farmer have not only been excluded from many benefits of technology but they have also been negatively affected by its application. As the improved fields are generally the men's or family plots, but rarely the women's, the women rarely benefit from their increased workload.

\section{STRATEGIES FOR INCREASING THE AGRICULTURAL PRODUCTIVITY OF WOMEN FARMERS}

In an attempt to identify the strategies for strengthening the role of rural women in increasing the agricultural productivity of rural areas, it will be necessary to identify their strengths and potentials, on which these strategies will be premised. It is widely acknowledged that women farmers are very hard working with so much done in an average day. Most jobs are done manually. If the domestic work of women farmers could be made lighter and easier through the provision of appropriate technology, much of her energies would be conserved for other productive ventures.

\subsection{Technologies Needed Particularly by Female Farmers}

Labour and energy saving technologies for the task of women farmers are essential. Post harvest machineries are equally important. Women farmers typically lack technologies to relieve time-consuming agricultural tasks such as weeding, transplanting, and harvesting. Grinding, transport, and water and firewood collection are the main non-agricultural activities where appropriate technologies can reduce the time and energy use of women farmers.

\section{Production Technologies}

Production technologies sustainable for women farmers must reflect their current disadvantaged access to most resources and their wide variety of productive activities. Women farmers use hand tools and equipment much more than men. About 30 to 50 percent of the harvest in Nigeria is estimated to be lost in the processing, drying and storage sequence (Olawoye, 1991). The processing of agricultural produce typically is carried out by women, often providing additional sources of income. However, given the primitive technology used, many agro-processing procedures consume much time and energy. Improvements in agro-processing and storage technologies together with better rural infrastructure, market information systems and transport could substantially raise labour productivity and yields.

\subsection{Experience of the Women Farmers}

The main potential which women farmers have for increasing agricultural productivity in the rural areas and thus improving the living standards of their families, is in their long experience as farmers coupled with tremendous store of knowledge and expertise on indigenous crop varieties and the special environmental requirements for cultivating livestock breeds. Women farmers understand the nutritional attributes of various local foods which they produce. Women farmers should be empowered and assisted to do better that which are known to do well. This enhances a sustainable improvement in agricultural productivity

\subsection{Access of Women Farmers to Basic Production Resources}

Access of women farmers to basic production resources - land, labour and capital for investment must be facilitated - specific efforts must be made to break through the social and intra-household constraints that impede accessibility of these resources. This will require special campaign programmes for sensitizing communities to the negative effects of excluding women farmers from ownership of land and access to critical resources. Out- reach programmes to overcome gender-specific constraints may require legal, administrative or even gender quotas.

\subsection{Market Outlets and Formation of Thrift and Credit Cooperatives}

Women farmers are known to have tremendous motivation once given the lead. They prove to be creative entrepreneurs and respond highly to market signals. It is imperative therefore to create market outlets for farm products and off farm products and off farm products of women farmers, most of which would develop into small scale industries with further expansion. The ability of a few women farmers to save from exceptionally meager incomes is demonstrated through thrift and credit co-operatives. In the few cases, where these women farmers gained access to formal credit from banks, they have proved to be highly creditworthy. Commercial and government banking services should explore more flexible and innovative credit 
schemes that require the type of collateral which women farmers possess and can present e.g. group guarantee. To mobilize and sustain gender solidarity for improved productivity, the co-operatives must not restrict themselves to their small women organizations but to participate in wider village associations which will help promote access of women farmers to education, agricultural extension management training and decisionmaking. The linkages within women farmers and the more organized professional women groups will facilitate this process.

\section{DEVELOPING SKILLS FOR WOMEN FARMERS}

Skills development is key to improving rural productivity, employability and income-earning opportunities, enhancing food security and promoting environmentally sustainable rural development and livelihoods. Despite women farmers' major role in agriculture and other rural activities, higher barriers in education and training limit their participation in more productive and remunerative work, perform managerial and leadership roles and participate full $\mathrm{y}$ in the development of their communities. Targeted action is needed to dismantle these barriers. Education and training are essential components of any strategy to improve agricultural and non-farm productivity and pull households out of poverty. Learning about improved production technologies and methods, new products and markets, business and life skills (such as health management, decision-making, self confidence, or conflict management) can make a big difference. Skills development is particularly important to women farmers who are more likely to be contributing family workers, subsistence farmers or home-based micro-entrepreneurs in the informal sector, or performing low-paid, unskilled work as seasonal workers. Women farmers often have different training needs than men, linked to their domestic work and care responsibilities, as well as to gender based divisions of labour for managing or undertaking specific tasks in crop, livestock, forestry or fish production and processing.

Skills development for women farmers and men often requires a combination of training in formal settings (such as schools and training institutions) and non-formal ones (such as community groups, NGOs, and learning from family and peers). It can comprise basic education, vocational and life skills training, entrepreneurship training and agricultural extension services. Policy makers should design and implement a package of complementary measures to address the specific needs of rural people at different levels.

\subsection{Skills Acquisition and Entrepreneurship}

Entrepreneurship is the process of identifying, developing, and bringing a vision to life. The vision may be an innovative idea, an opportunity, or simply a better way to do something. An entrepreneur is also viewed as an innovator. He introduces new ideas, new products, new techniques, and opens up new markets.. The entrepreneur thus perceives business opportunities and takes advantage of the scarce resources to use them. It is he alone who bears the non-insurable risk in the enterprise and directs the human and material resources towards his business objective. Skill acquisition on the other hand is getting all the necessary training and experience needed to carry out a trade or business successfully.

\section{SUGGESTIONS FOR IMPROVEMENT}

If women farmers must play their rightful role in rural development, a complete change along the following lines is suggested:-

(i) Process of Self Realization:

This process of self-realization can be brought about by education, discussions, participation at workshops and formation of associations and co-operative societies. This would help women farmers know specifically their duties, the changes that have affected them and how they can adapt to these changes.

\section{(ii) Building Viable Projects through co-operatives:}

There are many advantages in forming and belonging to co-operatives. They teach how to lead or follow others. They enable members to save and accumulate scarce capital for investment. Through cooperatives, women farmers can receive loans from banks and thus make possible small-scale industries in the rural areas such as garri processing, rice milling, soap making etc.

\section{(iii) Greater use of Indigenous Savings Groups:}

There should be greater use made of such indigenous savings groups. These groups, are valuable and stable in many rural communities, and can be modernized to achieve greater heights in the future.

\section{(iv) More Work for the Educated Women:}

The educated women should do more homework in their schedule of activities. These include:

(a) Mobilizing other women for rural development 
(b) Mobilizing rural savings and other sources of funds;

(c) Finding out areas of investment;

(d) Ensuring that governments listen to the voice of women through their participation in decision-making processes;

(e) Acting as 'Think-Tank' for the interest of women and general welfare'

(f) Production of statistical information on the progress of women;

(g) Ensuring a fair deal from government with budgets and banks with loans - so that women are not disadvantaged in any way.

\section{CONCLUSIONS AND RECOMMENDATIONS}

Food sufficiency can only be guaranteed by continued gender involvement in agriculture. There is therefore, the need for an aggressive approach to ensure that gender participation in agriculture is at an increasing rate. Also, Government agricultural policies and programs should not be gender specific .The importance of agriculture cannot be overemphasized. Therefore, for Nigeria to be able to feed her citizens and ensure food security, the following measures are suggested:

There should not be gender disparity or gender bias in agricultural policies and programmes implementation.

Government should invest more on women education, since development in all spheres of life including agriculture hinges on education of the people particularly women.

Women involvement in agriculture is on the increase compared to men, therefore they should be given appropriate types of technology to cater for the labour intensive farm activities, good financial support and access to more farm land through appropriate land reforms.

Farm inputs and other innovations should be available to women farmers at affordable and subsidized rates as and when needed.

For food security, gender division of labour according to tasks should be discarded and there should be equity in every aspect of agricultural activities.

Support systems for farmers within a holistic gender-sensitive framework are urgently needed to form a policy development agenda.

\section{REFERENCES}

[1] FAO - Gender, Key to Sustainedability and Food Security. Plan of Action. Gender and Development. Rome 2003

[2] Adu, A.O, Famuyide, O.O, Adejoba, O.R, Ojo, M.O, Thomas, E.Y. and Adebayo, O. (2003): Gender Issues in Agro Forestry Development in three selected LGAs of Oyo State. Proceeding of $29^{\text {th }}$ Annual Conference of the Forestry Association of Nigedria held at Calabar PP340.

[3] Akankpo, G.O. and Asa, U.A (2006): Gender Role in Maize Production in Ini L.G.A. Akwa Ibom State. Proceeding of $40^{\text {th }}$ Annual Conference of ASN held at Umudike Pp $606-609$.

[4] Annon, (2006): National Gender Policy; Federal Ministry of Women Affairs and Social Development printed by Amana printing limited Kaduna Pp 7-14.

[5] Ayoola, J.B and Odiaka, E.C (2004): Gender perspectives on Agricultural Development. Experience from Benue State of Nigeria. Proceeding of $38^{\text {th }}$ Annual Conference of ASN, Nasara P.

[6] Canada-Ukraine Gender Fund (2004): Canadian Charter of Rights and Freedoms: Concept of Gender and gender relations www.genderfund.com.ua

[7] CBN, (2006): Central Bank of Nigeria Statistical Bulletin.

[8] Frischmith, C. (1997): Gender is not a sensitive issue; Institutionalizing a Gender - Oriented Partici patory Approach in Savionga, Zambia TateKeeper Series No 72.

[9] Lawanson, T.O. (2010): Gender Differentials in Nigeria: Implications for Sustainable Urban development. Department of Urban and Regional Planning, University of Lagos Akoka Lagos.

[10] Meek, C.(1981): A Sudanese Kingdom, London: Kegan, Paul, Trench, Trubner and Co.

[11] NAERLS. (2000): An assessment of Contribution of Women to Family Farming in North- Eastern Nigeria. Report of a Research Sponsored by the National Agricultural Research Programme, Abuja, Nigeria. National Agricultural Extension and Research Liaison Service, Ahmadu Bello University, Zaria, Nigeria.

[12] NBS, (2007): National Bureau of Statistics; Agricultural Survey Report 1994 - 2006. Produced under th e Auspices the Economic Reforms and Government Project (ERGP) Pp $60-71$.

[13] Ngur, N., 1987. Women and development in crop and livestock production in Nigeria. Paper presentedat the eminar on Women Studies, University of Ibadan, Nigeria, 4-6 November 1987.

[14] Nnadozie, B. and I. Ibe, 1996. Women in agriculture: Problems and prospects, In: Agricultural Transformation in Nigeria, Eds., A. C. Nwosu; C. U. Nwajuba and J. A. Mbanasor. Owerri, Nigeria: Novelty Industrial Enterprises.Mohammed, B.T. and Abdulquadri, A.F: Continental J. Agricultural 
Science 5 (3): 35 - 40, 2011

[15] NPC, (2006): National Population Commission

[16] Olawoye, O.(1991) Technology needs of Rural Women.

[17] Rahman, S.A., 2008. Women's involvement in agriculture in northern and southern Kaduna State. Journal of Gender Studies 17:17-26

[18] Riley, Nancy E (1997) Gender, Power and Population Change Population Bulletin, vol. 52 No. 1(Washington,

[19] D.C. Population

[20] Sen.G. (1999)'Engendering Poverty Alleviation: Challenges and Opportunities', in Development and Change

[21] Simmons, E.B., 1973. The economics of consumer-oriented food processing technologies in FAO. Review on Agricultural Development No. 75 (13:40-41).

[22] UN-Habitat (2003) A Conceptual Guide to "Gender" http://www.unhabitat.org/gov 